\title{
Using the Predictability Criterion for Selecting Extended Verbs for Shona Dictionaries ${ }^{1}$
}

\author{
Emmanuel Chabata, ALLEX Project, \\ Department of African Languages and Literature, \\ University of Zimbabwe, Harare, Zimbabwe
}

\begin{abstract}
The paper examines the "predictability criterion", a classificatory tool which is used in selecting affixed word forms for dictionary entries. It focuses on the criterion as it has been used by the African Languages Lexical (ALLEX) Project for selecting extended verbs to enter as headwords in the Project's first monolingual Shona dictionary Duramazwi ReChiShona. The article also examines the status of Shona verbal extensions in terms of their semantic input to the verb stems they are attached to. The paper was originally motivated by two observations: (a) that predictability seems to be a matter of degree; and (b) that the predictability criterion tended to be used inconsistently in the selection of extended verbs and senses for Duramazwi ReChiShona. An analysis of 412 productively extended verbs that were entered as headwords in Duramazwi ReChiShona shows that verbal extensions can bring both predictable and unpredictable senses to the verb stems they are attached to. The paper demonstrates that for an effective use of the predictability criterion for selecting extended verbs for Shona dictionaries, there is need for the lexicographer to have an indepth understanding of the kinds of semantic movements that are caused when verb stems are extended. It shows the need to view verbal extensions in Shona as derivational morphemes, not inflectional morphemes as some earlier scholars have concluded.
\end{abstract}

Keywords: DEFINITION, DERIVATIONAL MORPHEME, DICTIONARY, DICTIONARY ENTRY, LEXEME, LEXICOGRAPHY, MORPHOLOGY, PREDICTABILITY CRITERION, SEMANTICS, SHONA, VERB STEM, VERBAL EXTENSION

Opsomming: Die gebruik van die voorspelbaarheidskriterium om uitgebreide werkwoorde te selekteer vir Shonawoordeboeke. Hierdie artikel ondersoek die "voorspelbaarheidskriterium", 'n klassifikasiehulpmiddel wat gebruik word om geaffigeerde woordvorme te selekteer as woordeboekinskrywings. Dit fokus op die kriterium soos dit gebruik is deur die African Language Lexical (ALLEX) Project vir die selektering van uitgebreide werkwoorde as lemmas in die Projek se eerste eentalige Shonawoordeboek Duramazwi ReChiShona. In hierdie artikel word die status van Shona se werkwoordelike uitbreidings ondersoek in terme van hul semantiese opname in die werkwoordstamme waarmee hulle verbind is. Die artikel is oorspronklik gemotiveer deur twee waamemings: (a) dat voorspelbaarheid ' $n$ graadkwessie is; en (b) dat die neiging bestaan het om die voorspelbaarheidskriterium in die seleksie van uitgebreide werkwoorde en betekenisse vir die Duramazwi ReChiShona inkonsekwent toe te pas. 'n Ontleding

This paper was presented at the Second International Conference of the African Association for Lexicography, held at the University of Natal, Durban, 14-16 July 1997.

Lexikos 8 (AFRILEX-reeks/series 8: 1998): 140-153 
van 412 produktief uitgebreide werkwoorde wat as lemmas in Duramazwi ReChiShona opgeneem is, toon dat werkwoordelike uitbreidings sowel voorspelbare as onvoorspelbare betekenisse kan toevoeg tot die werkwoordstamme waarmee hulle verbind is. Die artikel bewys dat dit vir die effektiewe gebruik van die voorspelbaarheidskriterium vir die seleksie van uitgebreide werkwoorde vir Shonawoordeboeke vir die leksikograaf noodsaaklik is om 'n grondige insig te hê in die tipes semantiese verskuiwings wat veroorsaak word deur die uitbreiding van werkwoordstamme. Dit toon die noodsaaklikheid om werkwoordelike uitbreidings in Shona te beskou as afleidingsmorfeme en nie as fleksiemorfeme soos sommige vroeëre vakkundiges besluit het nie.

Sleutelwoorde: DEFINISIE, AFLEIDINGSMORFEEM, WOORDEBOEK, WOORDEBOEKINSKRYWING, LEKSEEM, LEKSIKOGRAFIE, MORFOLOGIE, VOORSPELBAARHEIDSKRITERIUM, SEMANTIEK, SHONA, WERKWOORDSTAM, WERKWOORDELIKE UITBREIDING

\section{Introduction}

Headword and sense selection is an important stage in dictionary making, for it determines what to include in or exclude from a dictionary, a criterion that influences the usefulness of the dictionary for its target users. The selection process, therefore, needs well-formulated selection principles. The research reported on here is intended to be a contribution towards having clearly-defined principles for the selection of headwords and senses to enter in Shona dictionaries. Towards this goal, the article focuses on the use of the predictability criterion by the ALLEX Project, since, beyond the very general, what it actually refers to has not yet been explicitly explained in the style manuals developed within the Project.

The paper looks at the predictability/unpredictability concepts in general lexicographic practice and discusses the implications of using the predictability criterion for headword and sense selection in Shona lexicography. Specifically, it looks at the use of the predictability criterion for the selection of extended verbs and senses to enter in Shona dictionaries. Attention is given to the application of the criterion to extended verbs since there are contrasting views concerning the semantic input of Shona verbal extensions to verb stems. Earlier scholars treated verbal extensions as if they were inflectional morphemes, thus, as if they add little semantic meaning to base forms. However, this article considers Shona verbal extensions as derivational. Since this is not a traditional treatment of these morphemes, some space is devoted to explaining why these extensions should be considered derivational morphemes. The article also examines the typical kinds of semantic shift caused by the addition of verbal extensions to base forms. The semantic movements discussed are those that were discovered in the analysis of 412 extended verbs defined in Duramazwi ReChiShona. In the subsequent sections, therefore, the focus is on the use of the predictability criterion in the general lexicographic context, its use in the context of Shona lexicography, the nature of Shona verbal extensions and the semantic divergences caused by addition of verbal extensions to the 412 verb stems examined in the study. 


\section{The predictability criterion in the general lexicographic context}

The predictability criterion has a long and productive tradition of use in lexicography and is one that has been recommended by a number of lexicographers and lexicologists (for example, Zgusta 1971, Landau 1984, Jackson 1988 and Svensén 1993). According to The Oxford English Dictionary (2nd ed.), something that is predictable "is capable of being predicted or foretold". This follows its definition of the verb "predict" which reads "of a theory, observation etc.: to have as a deducible or inferable consequence; to imply". The predictability criterion has been used in compiling dictionaries for many languages, including Shona, mainly as a means for selecting derived word forms for dictionary entries. According to this criterion, if the meaning of a derived word form can easily be traced back to the meaning of the base form, it would be considered predictable and, as a result, excluded from the dictionary. On the other hand, if the meaning of the derived form cannot be traced, or is difficult to trace, from the base form, it would be considered unpredictable and would, therefore, be entered and defined as a headword. Zgusta (1971: 242), for example, argues that if there is a category of words constituted by a uniform derivation, for instance by the same suffix, and if the membership of this class is quite open, that is, if new members of the class is commonly produced and are easily understood, and if the semantic effect of the derivational process is as uniform as its form, it is not necessary to indicate in the dictionary all known members of the class. In this case, the lexicographer would enter and define the derivational morphemes, for example, highly productive prefixes or suffixes, where he/she feels it to be impossible to include all the instances where the prefix or suffix would occur. A note for the dictionary user would then be given to inform him/her of the meanings these morphemes would add to base forms.

From this perspective, it can be noted that if we use the predictability criterion for headword and sense selection, a derived lexeme can be omitted if both its form and meaning are regular and predictable from the derivative formula. Lyons (1977: 515) argues that if we think of the lexicon/dictionary as an appendix to the grammar, and, if we assume, moreover, that we are able to find the main lexical entry for each lexeme indexed by means of its citation form (which may or may not be a stem from which we can generate all the other forms), there is no need to contain these "purely morphological lexical entries". In fact, Lyons (1977: 515) regards these kinds of lexical entries as being "theoretically redundant".

However, as noted by Zgusta (1971: 242), when the predictability criterion is used, it is necessary for the lexicographer to study all the words in which the particular derivational morpheme occurs in order to see whether the semantic effect described by its "summary indication", that is, its definition, is really identical in all cases. He argues that the lexicographer is obliged to check every member of the category which would otherwise be eligible for selection in order to see whether some of the members do not have semantic "specialities" of their own, not shared by the other members of the class. In this regard Zgusta recommends that when the predictability criterion is used, any word 
that shows a semantic speciality, should be entered in the dictionary unless it is eliminated for other reasons such as rareness or obsoleteness.

Like Lyons (1977: 515), Zgusta (1971: 128) also notes that many dictionarjes do not list all the words that might be derived from base forms in regular or predictable ways. He is, however, quick to note that derivation is not perfectly regular or uniform in all cases. He points out that the problem is that the difference between the base and the derived form is sometimes great, whilst some meaning differences are not so great, but still observable. $\mathrm{He}(1971: 129)$ argues:

The greater the number of words in which the same derivational morpheme causes the same change of the lexical meaning, the smaller will be the inclination of the lexicographer to list all these words ... If a derivational morpheme is not frequent and/or if its modifying effect on the lexical meaning is far from uniform, the similarity to a grammatical function will be incomparably smaller and the lexicographer will be more inclined to indicate the respective words as separate items.

Swanson (1967: 64), however, is of the opinion that the predictability criterion, with its suggestions to make some derivational morphemes dictionary entries while eliminating derived forms as headwords or run-ons, can only be used efficiently and effectively by linguists. He argues that the use of this criterion would make access to headwords more difficult for readers not trained in linguistics. He also argues that the dictionary user cannot be expected to know how to identify morphemes that constitute derived word forms, since words are traditionally set off in the orthography by spaces. Swanson's view is derived from his observations of monolingual speakers and readers of English, a language whose spelling conventions favour a disjunctive system of word division. The orthographic word in the language under study, Shona, is conjunctively spelt in such a way that large amounts of grammatical and derivational information is put together in word form. An example is vachazoonana (they will eventually see one another), where the subject marker (va-), future (-cha-), auxiliary (-zo-), verb stem (-ona) and the reciprocal extension (-an-) are combined to form a single word. The marking of morpheme boundaries is problematic in Shona because of this conjunctive system. Swanson's view was confirmed for Shona by field research on extended verbs (reported in Chabata 1997) which showed that most tertiary students studying Shona structure did not mark morpheme boundaries correctly, nor could they always distinguish between the base form and verbal extension, knowledge that is needed in order to be able to add the meanings of the respective morphemes and to get the predictably extended meaning.

\section{The predictability criterion in the context of Shona lexicography}

The lexical tradition of Shona shows that, at least for Hannan (1959), extended forms, predictable or not, were selected as headwords. This however seems to be different for Dale (1981: viii) who claims to have used the predictability cri- 
terion for selecting extended verbs. For Duramazwi ReChiShona (Chimhundu 1996), a monolingual general Shona dictionary which targets O-level students and contains only.15 828 headwords, the predictability criterion was used for selecting derived word forms, including extended verbs. The idea was that unlike bilingual Shona-English dictionaries like Hannan's Standard Shona Dictionary which was meant mainly for second-language Shona speakers, Duramazwi ReChiShona was being developed for first-language users who were expected to easily understand predictably extended meanings of derived words. Thus in the process of headword selection, a decision was made that for certain categories of headwords, including extended verbs, only those which were commonly used and which had "unpredictable" meanings would be defined (Chimhundu 1992: 30). It was also decided that verbal extensions would be included as headwords, and that these would be defined. This was actually done in summary form in the front matter of Duramazwi ReChiShona (1996: xxiii) and in the body of the dictionary as well. The assumption was that if the targeted dictionary user studying Shona structure at secondary school wanted to know the meaning of an extended verb, he/she would have the knowledge needed to "add up" the meanings of parts of predictably extended verbs. For example, if someone wanted the meaning(s) of -famb-is-a (1. walk faster. 2. cause someone to walk), he/she would look for the meanings of -famb- (walk) and the relevant one of -is- (intensive or causative extension) in the dictionary and then "add" them "up".

The method of adding up meanings of the smaller units to get the meaning of the larger construction will in this article be called the analytical approach. This analytical approach is based on two assumptions, that is: (a) that there are lexical units which contain identifiable parts whose meanings, when combined, equal precisely the meaning of the lexical unit as a whole; and (b) that these would be easily identifiable and "addable". When this approach is used, the "theory" which makes predictability possible, assumes conscious knowledge of the derivational processes within the language by its target audience. In the case of extended verbs, the target users would be expected to know the meaning elements brought by the respective verbal extensions to unextended verb stems.

The predictability criterion, in the context of Shona lexicography, is needed for two main reasons. Firstly, it is needed to save space. Derivational processes in Shona are very productive. In fact, most Shona verb stems can produce through derivation a number of other verb stems which at times are analytically predictable. An example is -taura (speak/talk) which can be extended to yield highly predictable senses, for example:

-taurisa (+ intensive: speak loudly)

-taurira ( + applied: tell to somebody)

-taurika ( + potential: able to be spoken)

-taudzana (+ causative + reciprocal: cause one another to talk)

-taurirwa ( + applied + passive: be told by somebody) 
Inclusion of all these extended forms would take up unnecessary space since their meanings can easily be understood by adding up the meanings of the verb -taura and those of the respective extensions.

Secondly, it is needed to avoid redundancy. To include all derived verb forms would be superfluous, since in many cases the meanings of these forms could be traced quite transparently from the base form. As a result, Shona lexicographers have tended to adopt Tsonope's observation that "what is highly predictable is highly deletable" (Chimhundu 1992: 36).

However, despite the fact that it has had a relatively long and productive tradition of use for headword and sense selection within Shona lexicography, the predictability criterion presents problems. For instance, in Chabata (1997) it was shown that what might be predictable to one person, or a group of people, might not be predictable to another person, or another group. To illustrate this, we can take the example -bikira. This verb stem is derived by the addition of the applied extension -ir- to the root-bik-(cook). The sum total of the meanings of -bik- and -ir- would give us the meaning "cook for (somebody)". This meaning might be predictable to everyone. However, -bikira can have, at least for some Shona speakers, although not for all, another more specialised meaning "prepare a love potion". This second meaning might not involve cooking at all; a person could just do good things for his/her partner so that he/she is loved more. The meaning is therefore a meaning that has been transferred from the basic meaning, that is, a metaphorical meaning. Faced with the selection task, this verb might be "predictable" for some lexicographers, but not necessarily for everyone.

Another problem of using the predictability criterion is that despite the fact that any criterion suggests either the presence or absence of something, predictability is a matter of degree. We can have forms that are very predictable, others that are somewhat predictable or somewhat unpredictable, and still others that are very unpredictable. In the above examples we have seen cases where meanings can be somewhat predictable or somewhat unpredictable. However, in addition to these, there are some cases where we can have forms that look like extended verbs that have highly unpredictable meanings. An example of this can be -kanganwa (forget) in which, although extension-like elements (that is, the reciprocal -an- and the passive -w-) seem to be part of the stem, they cannot be related to any relevant roots, that is, -kang- or -kangan-. Although -an- and - $w$ - are forms of extensions in Shona, we cannot argue that in this example these are verbal extensions productively extending the verb stem -kanga. Instead, they form an indivisible part of the heavily lexicalised verb stem -kanganwa. This matter of degree makes the selection of derived forms difficult for the lexicographer using this criterion, for it is usually not easy to determine whether a form is very predictable, somewhat predictable or somewhat unpredictable.

Another problem stems from the treatment Shona verbal extensions have received from some scholars. A number of scholars (for example Fortune 1955, 1957, 1984, Dembetembe 1987 and Harford 1990) have written on Shona verbal extensions and extended verbs. In their analyses they focus on the form of the 
extensions, syntactic functions and, to a much lesser extent, the meanings of individual extensions. For example, Dembetembe (1987: 31) says:

Extensions are distinguished one from another by their shape, syntactic function and meaning. Of these, shape and meaning are obtained sub. tractively, and function by some form of transformation. Extensions have been identified in this study mainly on the basis of their shape and syntactic function. Meaning has been applied to a lesser extent for the simple reason that translation from Korekore to English is sometimes rather misleading.

Fortune $(1955,1957,1984)$ and Dembetembe (1987) deal with the effects of verbal extensions primarily at the morphophonological and the syntactic levels, and not at the semantic level, with the effect that some scholars (for example Harford 1990) actually refer to extensions as inflections, thereby suggesting strongly that these morphemes add little significant meaning to their respective base forms. At the morphosyntactic level, they focus on effects that can be deduced analytically, that is, those that are predictable. For example, they look at the generally predictable argument structures required by verbal extensions like the passive, applied, potential and the causative. Neither the derivational functions of extensions nor their semantic input to verb stems, therefore, have been traditional areas of study in Shona grammar.

However, recent studies in Shona morphology (Mkanganwi 1995, Chabata 1997) have shown that Shona verbal extensions are derivational, and not inflectional morphemes. There are a number of reasons for this. One reason why Shona verbal extensions are regarded derivational is because they usually change the meanings of the verb roots in question in highly significant ways. Because of this, the addition of verbal extensions produces new words that need to be added to the lexicon. If we take the example -radza (place a dead body in a grave), we note that the causative verbal extension -dz-adds a metaphorical sense to the meaning of the base form -rara (sleep). The semantic change is not wholly analysable from the construction since the meaning of the derived form has radically shifted from the meaning of the base form; a completely different event is being described.

Shona verbal extensions are also considered derivational because they typically (but not necessarily) change the syntactic category of the root (base form) to which they apply. In this case, a verb (V) can be derived from or changed into an ideophone (I), a noun (N) or an adjective (A). For example:

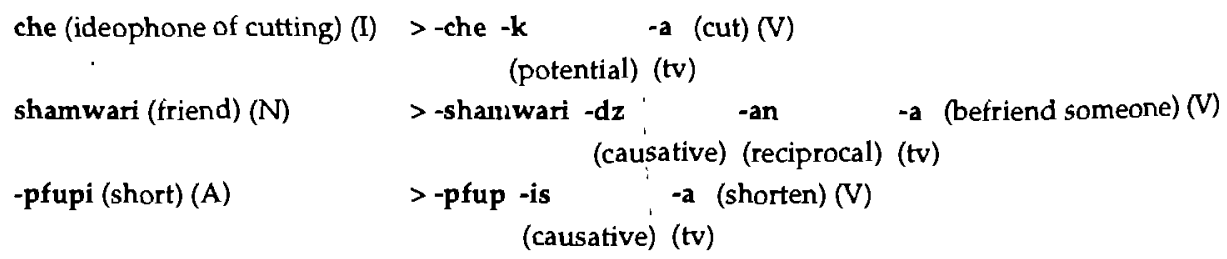


Mkanganwi (1995: 67) notes that, although some of these extensions do not change the word category of a form, they do move a form into a different syntactic subcategory and involve large meaning changes. For example:

$-f a m b-a$

(walk) (tv)
$>-$ famb -ir $\quad-\mathbf{a}$

(walk) (applied) (tv) (1. walk on behalf of 2. take responsibility)

As we can see, both -famba and -fambira are in the verbal category. The addition of the applied extension has resulted in at least two senses, one of which shows a radical change in the meaning of the base form, and as a result, is unpredictable. Syntactically, whilst -famba is a one-argument verb which may take an adjunct, the addition of the applied extension to it results in -fambira which is a two-argument verb which may or may not take an adjunct.

Another reason why Shona verbal extensions are regarded as being derivational is the amount of lexical generality they have. Bybee (1985: 84) for example argues that derivational processes are more likely to have lexical restrictions on their applicability. She goes on to note that derivational processes may be applicable only in very restricted semantic, syntactic and phonological domains. To illustrate this, we can take the potential/neuter extension -ik- which can be used to extend transitive verbs, but usually not intransitive ones. This extension can for example be suffixed to verb stems like -ba (steal) and -dya (eat) to result in -bika (able to be stolen; stealable) and-dyika (able to be eaten; edible) respectively. However, if -ik- is suffixed to -fa (die) and -tsva (burn), both of which are intransitive, the resultant forms, that is, ${ }^{*}$-fika (able to undergo dying) and *-tsvika (able to be burnt; burnable) would be unacceptable, despite the fact that the resulting forms were logically possible. Thus, verbal extensions, for example the potential, are less generalisable.

Bybee (1985: 17) also notes that for a morpheme to be generally applicable, it must have only minimal semantic content. With minimal semantic content, the meanings it would add, would be highly predictable. Derivational affixes such as Shona verbal extensions are not applicable to large numbers of stems in precisely the same ways because they have relatively high semantic content.

Shona verbal extensions are also considered derivational morphemes because they can cause large meaning changes to verb forms to which they are attached. The addition of verbal extensions can result in semantic divergences or movements of a number of types which cannot be understood by just adding the respective meanings of the unextended verb stem and that of the verbal extension(s). In the next section we will look at some of the movements that are caused by adding extensions to verb stems.

\section{Semantic divergences caused by extending verbs}

An analysis of 412 productively extended (to be defined below) Shona verbs discussed here shows that there are a number of types of semantic differences between extended and unextended verbs, most of which cannot be understood 
by the analytical approach. The addition of verbal extensions to verb stems can cause a stem which was not very specialised to become more specialised. Specialisation is explained by Ullmann (1964: 228 ) as follows:

The net result of the change is that the word is now applicable to fewer things, but tells us more about them; its scope has been restricted, but its meaning has been enriched with an additional feature.

A Shona example is:

-dyisa 1. unpredictable: feed someone with poisoned food. 2. predictable: cause someone to eat; feed someone.

This verb stem has been derived from -dya (eat) by the causative extension -is-. While -dya refers to eating in general and there is no specification of things that are eaten, one derived sense carries a specialised meaning which refers to feeding with poisoned food only. As we can see in this example, the shift in meaning results in the derived meaning of the verb applying to fewer situations than the base meaning, but it yields more information about those situations.

Kastovsky (1990: 78) argues that derivational morphology is usually associated with the process of specialisation of meaning. He notes that this may be due either to the derivational addition of certain semantic components, or to some change in the meaning of the constituents which results from the combination, or both. He also notes that, as a result of specialisation, the overall meaning of the derived form can no longer be deduced from the meanings of its constituents plus the knowledge of the word-formation patterns; rather, additional information is required. If we take the example that has been provided above for -dyisa, we would note that the morpheme-by-morpheme analysis of this verb stem would give us only the easily predictable and unspecialised sense, that is, "cause someone to eat; feed someone". The specialised sense cannot be deduced by using this approach.

This point is also noted by Lyons (1977: 524) who argues that the meaning of complex lexemes (which would include extended verbs in Shona) is more specialised than that of the lexemes from which they appear to be derived. He suggests that the reason for this could be that complex lexemes, like simple lexemes, once created and introduced into the language and passed into general currency, may be institutionalised and, by virtue of their use in particular contexts, develop more or less specialised senses.

The addition of verbal extensions to verb stems can also lead to generalisation of meaning. With respect to generalisation, Robins (1990: 344) notes:

Some words widen the range of their applications or meanings when they come to be used in situational contexts in which they were previously not used or with reference to elements of the contexts with which they were previously not connected. 
Although Robins is writing about English here, this generalisation could also be applied to Shona in which the addition of a verbal extension to a verb root may lead to a generalisation of the meaning or reference beyond the confines of the meaning of the base form. An example is -sunga (tie). A verb stem -sungira is derived from -sunga by the addition of the applied extension -ir-. The analytic analysis of -sungira gives us the combined meanings of -sunga and the -irextension "tie someone". However, the applied extension has also generalised the meaning of -sunga. Whilst -sungira still has the element of using a rope to tie in some contexts, its meaning has been extended to also refer to the act of "carrying out a traditional prechildbirth ceremony". In this sense therefore, the verb stem applies to more contexts than its literal meaning would suggest.

It is however important to note that specialisation and generalisation seem to function merely as cover terms that have been applied to the different kinds of semantic change brought to verb stems by verbal extensions. The addition of verbal extensions to verb stems seem to cause meaning changes along relatively specific paths of divergence. This was shown by Chabata (1997) in his analysis of extended verbs that had been entered and defined in Duramazwi ReChiShona. The primary data was a set of 412 productively extended verbs and their definitions selected from this general Shona dictionary. An extended verb stem was considered to be productively extended if the stem had a literal, basic sense that is commonly used and/or if the extended form, together with its commonly used sense, serves as a base for other extended forms. These were the forms that were considered to be prototypically and productively extended but not lexicalised verb stems.

Out of 15828 headwords selected in all for Duramazwi ReChiShona, 6634 were verbs. Of these, about 2000 seem to have been extended in one way or another. Of these 2000 , about 1588 appeared to be lexicalised forms, that is, meaning shifts had merged in such a way that the sense was no longer traceable back to the senses of the morphemes that made it up. An extended form was considered lexicalised: (a) if its sense was not analytically predictable, for example the relationship between -femba (sniff) and -femb-er-a (guess); (b) if, although extension-like elements seem to be part of the stem, they can no longer be related to the roots, for example -kanganwa and -kanganisa, which cannot be related to either-kangana or -kanga; and/or (c) if the forms cannot be used productively as base forms for other extended verbs. It is however important to note that the "lexicalised" category (through which the data was narrowed) was of necessity an artificial category, since there was no clear separating line between "lexicalised" and "nonlexicalised" forms. Of the 412 that were analysed, about 259 were provided with fully predictable senses. These forms had been included because they were commonly used in everyday speech. There were about 153 verb headwords for which at least two senses had been defined and where one defined sense was not analytically predictable. Attention was then given to the defined sense that was not analytically predictable, in order to understand better how the sense moved away from the basic literal sense. Categories which were called "meaning shifts" or "paths of 
divergence" were developed. Some of the "paths" that were discovered include the following:

- Literal to metaphorical - where the description referred to by the unextended verb is transferred to some other description different from but analogous to that to which it is "properly" or literally applicable.

- Inclusive to exclusive - where the addition of the extension would lead the extended form to refer only to one thing or a small group of things rather than everything that the unextended form may refer to.

- Neutral to descriptive - where a neutral verb becomes descriptive and comments on some activity.

- Nonemotional to emotional - where the addition of an extension changes the meaning of the unextended verb from referring to physical activities to refer to activities that are connected with, based upon or appealing to the feelings or passions.

- Reversive - where the meaning of the extended form seems to contradict the meaning of the base form.

- Nonhabitual to habitual - where the addition of a verbal extension to a base form referring to one event or occasion changes the meaning to refer to something that is existing as a settled practice which is constantly repeated.

- Shift of reference - where the addition of an extension leads verbs to change from referring to an action or process to referring to a resultative state that has nothing to do with the named action or process.

- Physical to mental - where the addition of a verbal extension to a verb stem causes a change in reference from physical to mental, the mind and thought.

- Intensity - where the meaning of the extended form shows that something has been done excessively, more than in the unextended sense.

Verb senses were then sorted into these developing categories and it was discovered that although many senses fell into more than one category, there was usually a "primary" or "salient" path along which the sense seemed to have travelled. In some cases, senses seemed to have moved along two prime paths. To illustrate this we can take the example -pindira:

-pindira 1. unpredictable: make the wife of a man who is infertile, to bear children, which is usually done by (one of) the man's younger brothers. 2. literal and predictable: enter (a house) for or on behalf of someone.

The addition of the applied extension,-ir- to -pinda (enter a house) has, as we can see from the first sense of this example, shifted the meaning of -pinda to a sense that is metaphorical. The sense is metaphorical in that the act of -pindira may not even involve the sense of entering a house; a man would just need to have sex with his brother's wife so as to produce children. Besides being meta- 
phorical, the meaning is also exclusive because it does not refer to having sex with anyone's wife. In addition, the act is restricted to the wife of one who is infertile. Furthermore, the agent of the action is also restricted only to (one of) the husband's younger brother(s).

The extended verbs were re-sorted according to extension to see if any patterns emerged. These are summarised in table form:

\section{SEMANTIC DIVERGENCES FOR EACH VERBAL EXTENSION}

\section{Extension Type \\ Number of Forms with Unpredict- able Senses}

$\begin{array}{ll}\text { Causative } & 26 \\ \text { Applied } & 68 \\ & \\ & \\ \text { Perfective } & 13 \\ \text { Potential } & \\ \text { Passive } \\ \text { Reciprocal }\end{array}$

26

68

13

6

4

7

1

0

0

28

\section{Meaning Shift}

Percentage of Unpredictable Senses

Metaphorical
Exclusivity
Metaphorical
Description
Emotional
Reversive
Habitual
Emotional
Exclusivity
Shift of reference
Metaphorical
Mental
Emotional
Intensity
0
0

Exclusivity

Description

Reversive
77,9

22,1

35

25

18,3

11,7

10

25

75

100

100

59,1

40,9

100

0

0

36,5

51,1

12,4

The table shows the kinds of meaning shifts that each extension brought to the extended verbs that were studied. The summary of this table indicates that the applied extension can bring a wider variety of meaning differences to stems than any other extension and that at the other end of the scale, the intensively and the reversively extended stems brought with them no meaning shifts at all. Shifts in the directions of metaphorical, emotional and exclusivity spread across the widest variety of extensions and combined extensions.

\section{Conclusion}

In this article, we have seen that the addition of verbal extensions to verb stems may result in meanings that are either predictable or unpredictable from the 
meanings of their parts. We have also seen that the unpredictably extended definitions provided for the examined verb stems diverged in certain specific ways. While it is tempting to think that these divergences "belong" to productively extended verb stems, there is the possibility that these could be typical paths along which derived meanings diverge in general. In either case, additional research is needed. At the same time, developing a deeper sense of how meanings move away from the literal, noncommenting and nonevaluating meanings "predicted" by morphological analysis of productively extended verbs may help definers make more informed choices when they are selecting unpredictably extended verb stems. The definer could for example ask a set of questions about each verb stem - Is this metaphorical, emotional, descriptive, and so on? - in order to select verb headwords using a more delicate set of criteria than the very general predictability criterion.

An exploration of the predictability criterion has shown that this criterion can be used to save space and to avoid redundancy by excluding extended verbs that are analytically predictable, that is, those of which the senses can be understood by adding up the meanings of the base form and those of any extensions found in the stem.

This study has focused on the derivative nature rather than on the grammatical effects of verb extensions, showing that they are highly relevant (in the sense of Bybee 1985), that they have a high semantic content, and that they yield new lexemes that often need separate treatment in the lexicon of the language. We have also seen the need to view verbal extensions as derivational morphemes if the use of the predictability criterion is to be helpful in the selection of Shona extended verbs and senses.

\section{References}

Bybee, J.L. 1985. Morphology: A Study of the Relation between Meaning and Form. Philadelphia: John Benjamins.

Chabata, E. 1997. Applying the Predictability Criterion to Extended Verbs: A Study of a Headword and Sense Selection Problem in Shona Lexicography. Unpublished M.A Dissertation. Harare: University of Zimbabwe.

Chimhundu, H. (Ed.). 1992. Report on the African Languages Lexical (ALLEX) Project Planning and Training Workshop. Harare: Department of African Languages and Literature, University of Zimbabwe.

Chimhundu, H. (Ed.). 1996. Duramazwi ReChiShona. Harare: College Press.

Dale, D. 1981. Duramazwi: Shona-English Dictionary. Gweru: Mambo Press.

Dembetembe, N.C. 1987. A Linguistic Study of the Verb in Korekore. Harare: Zambezia, University of Zimbabwe.

Fortune, G. 1955. An Analytical Grammar of Shona. Cape Town/New York: Longmans and Green.

Fortune, G. 1957. Elements of Shona. Harare: Longmans.

Fortune, G. 1984. Shona Grammatical Constructions. Vol. 2. Harare: Mercury Press.

Hannan, M. 1959. Standard Shona Dictionary. Harare: The College Press and The Literature Bureau. 
Harford, C. 1990. The Applicative in ChiShona and Lexical Mapping Theory. Mchombo, S.A. (Ed.). 1990. Theoretical Aspects of Bantu Grammar. Stanford: CSLI Publications.

Jackson, H. 1988. Words and their Meaning. London/New York: Longman.

Kastovsky, D. 1990. The Interaction of Semantic and Formal Structures in the Lexicon. Tomaszczyk, J. and B. Lewandowska-Tomaszczyk (Eds.). 1990. Meaning and Lexicography. Amsterdam/Philadelphia: John Benjamins.

Landau, S.L. 1984. Dictionaries: The Art and Craft of Lexicography. New York: Cambridge University Press.

Lyons, J. 1977. Semantics. Vol. 2. New York: Cambridge University Press.

Mkanganwi, K.G. 1995. Shona: A Grammatical Sketch. Harare: Department of Linguistics, University of Zimbabwe.

Murray, J.A.H. (Ed.). 19892. The Oxford English Dictionary. London: Clarendon Press.

Robins, R.H. 1990. General Linguistics: An Introductory Survey. London: Longman.

Svensen, B. 1993. Practical Lexicography: Principles and Methods of Dictionary-making. Oxford/New York: Oxford University Press.

Swanson, D.C. 1967. Recommendations on the Selection of Entries for a Bilingual Dictionary. Householder, F.W. and S. Saporta (Eds.). 1967. Problems in Lexicography. Bloomington: Indiana University/The Hague: Mouton.

Ulmann, S. 1964. Semantics: An Introduction to the Science of Meaning. Oxford: Basil Blackwell. Zgusta, L. 1971. Manual of Lexicography. The Hague: Mouton. 